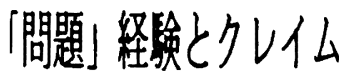 \\ 一構策主義の社会問題研究によせて— \\ Experience of "Problems" and Claims-Making: \\ On the Constructionist Study of Social Problems
}

草楖千早

KUSAYANAGI Chihaya

\begin{abstract}
This paper examines interactional processes through which personal difficulties or problems as experienced are defined and through which claims are made. First, I look into the constructionist idea of "claims." Then, the interaction between claimants is viewed as a reality-definition contest. I examine and develop the description of reality-definition contests formerly given by Loseke(1987). With an illustration of a case of claims-making regarding "fufu-bessei "(an argument against changing a married woman's surname to that of her husband), I discuss and show how one's experience and definitions of problems are involved and invalidated in the mechanism of reality-definition contests.
\end{abstract}

1.はじめに一一構筑主義とクレイム申し立ての研究

社会問題の経鞈的研究において、『社会問題の構策」(Spector \& Kitsuse 1977)に始ま る楆策主義は、人々のクレイム申し立て活動に焦点を当てた。その基本にある発想は、社 会問題は社会のメンバーによるクレイム申し立て活動を通じて構筑される、というものだ。 これに基づけば、社会問題研究は、何か固有の「問題」ある「社会状態」に関する客钼主 義的な研究ではなく、「ある状態が存在すると主張し、それが問題であると定義する人々 による活動」(Spector \& Kitsuse 1977:訳117)に関する研究に向かうことになる。そこで は専門家が何らかの「状龍」を「問題」であると診断し研究する営みもまた、「問題」が 定義されていく社会過程の部分ということになる。

では、社会問題が人々のクレイム申し立て活動を通じて構筑されるのだとすれば、人々 は、いかにして自分たちの経験する様々な問題やトラブルを「問題」として定義し、クレ イムを申し立てているのだろうか。これがここでの問いである。

人々が問題」を释検しクレイムを申し立てていく過程一ここれを社会問題研究の射程 に入れたのは、確かに構策主義であった。だが、この過程をめぐる考察は、いまだ展開の 途上にあるように思われる。ひとつには、構筑主義の方法に対する批判をめぐって論争が 起こり、ここ数年議論のアジェンダがメタレベルに引き上げられてしまったという経緯が ある。論争の詳細はすでに中河 $(1991,1992)$ 、ミラーとホルステイン(1993)等が紹介・検 討を加えているので(1)、ここでは簡単に述べれば、その引き金は、ウールガーとポーラ 
ッチの批判(Woolgar \& Pawluch 1985)である。彼らは、構策主義の議論には「社会状態」 についての客観主義的説明という自ら批判していたはずの説明が混入していると告発した のである。すなわちそこには、「社会状態が変化したわけではないのに、人々の定義は変 化した」といった説明が散見され、それらは、「社会状热は不変」という「状態」に関す る客観主義的な説明であり、同時にまさしく一つの定義活動ではないかというのである。 こうした告発は、構筑主義の社会問題研究に固有の問題にとどまらず、社会現象に関する 社会学的説明一般に数衍され、諭争は、結果的に構策主義的研究の関心をきわめてメタレ ベルへと追い立てることとなったのである。

この論争を経て、今一度構筑主義の社会問題研究のありうべき方向を展望しようとする のが、論文集【構筑主義再考】(Holstein \& Miller 1993)であり、その柱となるイバラと キツセの「道徳的ティスコースの日常言語的な構成要素—社会問題研究のための相互行 為論の立場からの一提案—」(Ibarra \& Kitsuse 1993) であろう。だが、彼らの言う

「新たな理論的展開の道筋を示すため」(Ibarra \& Kitsuse 1993:30)の提案もまた、人々 がいかして「問題」を経唪しクレイムを申し立てるのかという過程を照らし出すものと は言いがたい。

イバラとキツセの提案とは、ひとことで言えば「社会問題ティスコースの理論」を発展 させること、人々が社会問題を定義すべく用いる日常言語的な資䃇としてレトリックを研 究していくことである。彼らは、「状態カテゴリー」(Ibarra \& Kitsuse 1993:30)という 用語を用いて、あくまで「状態」ではなく「状態についての人々の語り」についての研究 を押し進めようとする。「状態カテゴリー」とは、社会的リアリティについて意味ある記 述や評価を生み出すために人々が用いるカテゴリーを表す ${ }^{(2)}$ 。社会問題は、こうした状 態カテコリリーを含む「イディオムの産物」とされ、そうしたイディオムを紡ぎ出す人々の コミュニケーション活動は「言語ゲーム」(Ibarra \& Kitsuse 1993:32)として捉えられる。 彼らは、社会問題のクレイム申し立てを、より笽格に言語的な次元で研究することを求め、 またそのための概念装置の精豭化をめざしたのである。

こうして社会問題研究の焦点は、人々が「社会問題」を訴えるために用いる日常言語的 な資䃇、クレイムのレトリックとその応酬へと絞られていく。イバラとキツセは、レトリ ックを大きくイディム、対抗レトリック、モチーフ、スタイルの 4 つの次元で研究する ことを提案し、さっそく見本演技を披露する。例えば、社会問題のレトリックのイティオオ ムにはどのようなものがあるか。彼らは、表失のレトリック、権利のレトリック、危機の レトリック、不合理のレトリックなどを列挙する。例えば、丧失のレトリックは、かけが えのない事物や特性が失われようとしているといった状態力テコリーを含むレトリックで あり、それを救うために何らかの手が打たれなければならないといった道徳的な要請と結 びつく。「野性動物を絶瑊から救おう」などがその典型である。

このようなティスコース研究は確かに、「状態」ではなく「活動」を、という構策主義 当初からの方法論的要請に治った一つの回答ではある。しかしそうした研究は、社会問題 をめぐる人々の活動過程をきわめて限定的にしか捉えないものになっているのではないか と思われる。第一に、それは、クレイムを経軮的に接近可能な対象として取り扱うことに よって、クレイムを申し立てる人々の活動過程の研究というよりも、申し立てられたクレ イムの研究とでもいうべきものになっている。そこでは、「社会問題のクレイム」として 
同定される言語的あるいは拡大してオーディオウィジュアルな対象が関心の焦点であり、 クレイムそれ自体が生み出されてくる過程は視野の背景に後退することになる。さらに、 このような研究は、後で考察するように、何が「社会問題のクレイム」なのか、またそれ を同定するのは誰なのかという、それ自体人々によって争われうる問いに対して、予め答 えを持ち込むという困嫤を招き寄せることになる ${ }^{(3)}$ 。

では一体、人々が日常生活のある局面を「問題」として経検しクレイムを申し立ててい こうとする過程とは、どのようにして捉えられるのだろうか。この問いにこたえるために、 ここでは一つの仮説的な枠組みを提示する。それは、社会問題をめぐる人々の相互行為過 程を、リアリティ定義の競合として捉え直す試みである。リアリティ定義の競合とは、口 一セク(1987)によって相互行為過程の記述に用いられた概念である。ここでは、構策主義 当初の「クレイム」概念に今一度戻りながら、ローセクの議論を一つの手掛かりに、問題 をめぐる人々の応酬をリアリティ定義の競合として提え直していく。それによって、「問 題」を経炴しクレイムを申し立てるという実践自体が、相互行為過程におけるきかめて微 妙で不確かな樌箘物として成立するものであることを示していく。またそこから、このよ うな人々の「問題」をめぐる営みが巻き込まれていく相互行為と相互経験の過程を、䤲筑 主義的な社会問題研究の射程に入れていくべき固有の領域として照らし出していきたい。

\section{2. リアリティ定義としてのクレイム申し立て}

まず、構筑主義が概念化したクレイム申し立てとは、どのような実践だったのか。一旦 「クレイム」概念に立ち戻り、それが、リアリティ定義の提起として捉えられることを述 ベ、リアリティ定義の競合という枠組みへの接続を準備する。

スペクターとキツセによれば、クレイム申し立て活動とは、「ある状態か存在すると主 張し、それが問題であると定義する人ひととによる活動」(Spector \& Kitsuse 1977: 訳117) である。しかも「クレイム」とは、常恶の一部、「社会的に構成されたカテゴリー」であ る(Spector \& Kitsuse 1977:訳124,125)。何がクレイムか否かは、社会のメンバーによっ て決定されるのであり、専門家がそうした人々の営みと独立に定義するのではない。クレ イムとは、申し立てる者と受け取る者との相互行為過程の内にあり、申し立てる者に定位 すれは「問題」経験に基づいて対他的に「問題」を定義し表明するもの、一方、社会のメ ンバーによって日常的に構成されるものなのだ。

ここには、クレイムが、二重の定義を通して具現化することが含意されていると言える。 第一に、まずクレイムを申し立てようとする者か、ある「状態」を「問題」として定義す るということ。第二に、そのような定義活動を、当人も含めて人々が「クレイム」として 定義するということ。この二つの手続きは必ずしも連結しているわけではない。つまりあ る者がある「状態」を「問題」として定義し、それを人々が「クレイム」として受けとる 場合がすべてではない。「ある状態」を「問題」として定義し表明しても、「クレイム」 として捉えられない、逆に問題」を何も定義していないにもかかわらず「クレイム」を 申し立てているとされる場合も考えられる(4)。

「問題」をめぐるクレイムの応酬と呼ばれるものは、この二重の定義に関わる応酬なの である。第一の定義、すなわち、ある状態が存在すると主張しそれを問題であると定義す 
る、このような定義は、言わば「状態」をいかなるものとして経硂しているのかの表明で ある (5)。そしてこのような定義活動が意味を持つのは、われわれが “同じ”日常生活世 界に生きており、なおかっにここで起こっているのは何か」の経験(Goffman 1974:8) は多 様でありうるという前提に立っているからである。人々は“同じ”事態を経験しうるが、 その “同じ”事態が人によって「問題」として感じられたり感じられなかったりしうると いう可能性の想定—そこに、問題」を定義し表明していく営みが意味あるものとして なされる素地がある。もし皆が “同じ”ことを同じように問題」として経硢するなら、 そもそも「問題」を定義し表明する必要はなく、逆に“同じ”ことを経唋できないなら、

「問題」を訴えても無䭾である。例えば、“同じ”結婚改姓が、ある人々には幸せとして 経験され、別の人々には不便や苦痛を強いる「問題」として経跧される。この “同じ”事 柄をめぐる問題経験のズレが、夫婦別姓というよく知られたクレイム申し立て活動を生み 出しまた成り立たせているのである。

こうして、ある「状態」を「問題」として定義する活動は、“同じ”事態を「問題」と して経験していない人々のリアリティ定義に対して、オルタナティブなリアリティ定義を 提起することと言える。クレイムを申し立てる者は、他の人々に対して、彼らが問題」

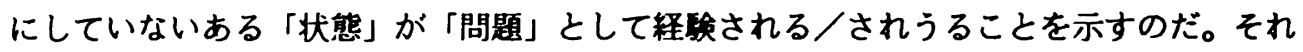
は、人々が保持してきたリアリティ定義——にこには問題はない」などと意識されるこ とさえない一に挑戦し、別のリアリティ定義——にこに問題がある」一を対置する ことである。

もちろん、異なるリアリティ定義がいつも対置・対決の関係にあるわけではない。それ どころか、われわれの日常生活は、様々な異なるリアリティ定義が折り重なり合う世界で ある。だが、クレイムを申し立てる者は、「問題」の解決、改善を期待しており、そのた めに自分の経倹している「問題」が他の人々にも「問題」として受け入れられることを期 待する。つまり人は、自分のリアリティ定義が、他の人々の保持してきた定義を溹鴐する ことを期待するのである。それに対して他の人々が彼ら自身の定義を保守しようとすると き、「問題」の有無、また何が「問題」なのかをめぐって異なる定義が競合することにな る。これが「リアリティ定義の競合」(reality-definition contests) である。こうして、 クレイムとカウンタークレイムの応酬、問題を経検している者と経検していない者との応 酬は、「リアリティ定義の競合」過程として捉えられるのである。

加えてさらに、先に挙げたもう一つの定義が、問題」をめぐる応酬には関わっている。 すなわち、第一の定義活動を「クレイム」として定義する営みである。実のところ、ある 「状態」の「問題」についての定義の競合であるだけならば、「問題」をめぐる応酬は、 イバラとキツセのいう「状態カテコリー」という概念で充分捉えられるとも言える。すな わち、「問題」をめぐる広酬とは、異なる状態カテゴリーの競合であると。しかしながら、 この応酬にはもう一つの定義、「問題」を定義し表明する活動を「クレイム」の申し立て であると定義する営みが関わっている。

「クレイム」という定義は、「問題」を定義し表明する側と受け取る側双方が行う、 「いまここで起こっているのは何か」についての定義である。それは単に受け手が「問 題」表明者の語りについて行う判断ではない。そこには、問題」の定義と表明がなされ ている今この場の状况、申し立てを行う人々と受け手の人々の相互行為、双方それぞれの 
アイデンティティと相互関係、ふるまいやその流儀、言及されている「状態」についての 互いの経硂・知識等々を含むきわめて広範囲で、言わばとりとめのない状況全体について の経埃が関わっている。スペクターらの挙げる例を引けば、郵便局の運営のずさんさを訴 える熱心なスピーチも、大学の東洋宗教の譜義中、それまで㷛って嚼講していた学生によ って笑然始められたなら、「クレイム」どころか「変人の奇行」として定義されてしまう (Spector \& Kitsuse 1977: 訳126)。こうした定義は明らかに、学生の話の内容そのものに ついての定義ではなく、状況全体のリアリティについての定義の部分として生み出される ものである(6)。

クレイムの洲、「問題」をめぐるやりとりには、社会的カテゴリーとしてのクレイム の性格上、二重の定義が関わっている。それらの定義は、問題」として言及される「状 態」がどのようなリアリティとして経倹されるのか、加えて、そうした問題」経确の表 明をめぐって今ここで起こっていることがどのようなリアリティとして経験されるのか、 を含むきわめて全体的なリアリティ定義である。「問題」をめぐるゃりとりは、問題」 として言及されているある「状態」についての定義の競合—「状態カテコリリ」の競合 一をはるかに超えた、リアリティ定義の競合なのである。

このようなリアリティ定義の競合という枠組みにおいて見れば、構筑主義が主題化しよ うとしてきた、いわゆる「クレイム」の応酬は、リアリティ定義の競合の一形態というこ とになる。またこの視点から見れば、イバラとキツセが提案するクレイムのレトリックの 研究は、「クレイム」として既に定義された言語的な対象に注目し、それが「問題」をい かに定義するものであるかを問うという、限定的な研究であると言えるだろう。

\section{3.「問題」をめぐるリアリティ定義の競合}

こうして、「問題」をめぐる人々の応酬は、リアリティ定義の競合として捉えることが できる。では、リアリティ定義の競合とは、どのような過程であり、クレイムを申し立て ようとする人々はこの過程にどのように巻き込まれていくのか。ここでは、ローセクの議 論(Loseke 1987,1989, Loseke \& Cahill 1984)を参考にし、次いでこれに検討を加えてい く形で、リアリティ定義の競合過程を描いていく。ローセクは、夫に虐待された妻たちと 保護施設のワーカーとのやりとりにリアリティ定義の競合を見出した。

（1）リアリティ定義の競合過程—ローセクのケーススタティ

ローセクは、妻の䖒待という社会問題のケーススタディを通じて、ニつのリアリティが 競合する样を考察した。その二つとは、「妻の虐待」とは何か」について、専門家の定 義する公式リアリティ(the official reality)と、妻の生きられたリアリティ(lived realities) ないし主钼的リアリティ(the subjective realities)である。妻の虐待とい う問題自体、かって単なる私的トラフルとされていたものが、クレイム申し立て活動によ って社会問題として取り組まれるようになったという経緯があるのだが、ここで报われる のは、この経緯から生まれた専門家と妻の間のリアリティ定義の競合である。

「妻の虐待」とは何加、専門家の公式定義ではそれは、夫による(1)激しく、(2)释り返さ 
れ、(3)身体に傷痕を残す、(4)心理的に賃痕を残す、(5)意図的な、身体的暴力であり、この 定義は、妻を保護する施設でワーカーによって各ケースに適用される(Loseke 1987:231232）。つまり個別のケースが「妻の虐待」であるかどうか、妻を保誏すべきかどうかの 判断は、妻の主観的リアリティに依执して語られるストーリーが公式定義にどれだけ当て はまっているかに基づいてなされる。妻の生きられたリアリティは、専門家の公式のリア リティ定義を通じて、再定義され、分類され、対処されるというのである。

ローセクは、このようなワーカーと妻の間に二つの形でリアリティ定義の競合が生じて いるという(Loseke 1987:236)。一つは個人のパーソナルアイテンティティをめぐる競合。 一方の定義が、他方のアイデンティティを規定するのである。妻とワーカーの場合、妻の、 虐待された妻という自認がワーカーの観点から否定されたり、逆に自認のない者が、虐待 された妻、しかも正しい自己認諎のない者として保護されるということが起こる。

第二に、直接経呤の意味をめぐる競合。一方の定義が他方がどのような状況にあり何を 释耠しているかを規定する。妻とワーカーの場合、妻の経験か、ワーカーによって再解那 されたり無視されるということが起こっているというのである(Loseke 1987:237)。夫婦 の間で何が起こっているのか、妻よりもワーカーの方が心得ているとされるのである。

これが、“同じ”「妻の虐待」という事態をめぐるリアリティ定義の競合である。競合 は、参加者のアイテンティティおよび直接経験の意味をめぐって展開し、一方の定義が他 方を淩駕する。そして、この競合に淩駕される形で巻き込まれた者は、自分のアイデンテ イティおよび直接経験の意味に対するコントロールを失っていく、というわけである。し かも、アイデンティティと直接経験の意味とは、ローセク自身も後に言及するように、わ れわれの経験の中で密接に関係づけられている(7)。例えば、「お前はいい子だ」という 属性付与は、それに相応しい释検以外の释験をしてはいけない、するはずがない、という 命令である(Laing 1961-1969:135) ように。一方を規定されることは、他方を規定される ことなのである。

ここには、問題释釦に依扴して何が問題なのかを定義しクレイムを申し立てるという人 々の実践が、それ自体相互行為においてきわめて微妙な形で成立しうるものであることが 示唆されている。「問題」をめぐるやりとりをリアリティ定義の競合として見るならば、 一方の人々が自分たちの問題経検を「社会問題」として定義していく過程は、同時に“同 じ”事態を「問題」として経検していない他方の人々によって彼らや彼らの活動が定義さ れていく過程でもあるものとして浮かび上がってくる。クレイムを申し立てるという実践 は、「問題を感じる」という経験に裹打ちされ、そうした経匰をしている自己への確信に 支えられている(8)。だが人は、問題」を経験しても、それを経験していない他者のリ アリティ定義に既され、その钼点からアイテンティティと直接释耠の意味をより強力に定 義され、訴えそれ自体を無効化されてしまう、ということが示されたのである。

（2）リアリティ定義の競合のメカニズム

ローセクのケーススタティから、リアリティ定義の競合という図式の概略は得られた。 では、このような競合において一方のリアリティ定義が他方を倰駕するというのはどのよ うなメカニズムにおいてなのか。 
先に述べたように、日常生活は、様々な異なるリアリティ定義が折り重なり合う世界で ある。そのような世界で、「問題」を経唋する者は、その解決を求めて「問題」を定義し 表明しょうとする。それに対して受け手㑡の人々は、この定義を受け入れて自分たちのリ アリティ定義を変容させるか、あるいは逆に自分たちのリアリティ定義によってこの定義 を再定義しようとする。このようなリアリティ定義の競合において、自分の定義によって 他者の定義を倰鴐し排除していこうする営みを作動させるのは、他者のリアリティ経耠を 不適切なもの、無効なものと見なす認定である。自らの定義をより適切なもの、正当なも の、それに対して他方を不適切なもの、誤りであり是正すべきものとする、この認定が、 リアリティ定義の競合を作動させ、またその競合への参加に根掤を与えるのである。だが、 この認定もまたリアリティ定義の一部なのである。

ローセクのケーススタディでは、二つのリアリティ定義の一方が公式的で客锂的なもの、 他方が主観的なものとされ、後者が前者によって再定義されていく様を描かれた。だが、 ここで重要なのは、あるリアリティ定義が客镅的であり、別の定義が主铸的であるといっ た認定、また専門家の客観的な定義が素人の主観的な定義よりも礁かであるという認定自 体、人々の定義によるものということだ。

ポルナーは、世界について相矛盾した複数の経検があることを、レインの議論(Laing 1965:35-36,1967) を参照しつつ「リアリティ分離」(reality disjunctures)(Pollner 1987:69）と呼び(9)、リアリティ分離に㗐む人々が、競合する経験の中からどれが正し くどれが誤っているかを決定することに含まれる問題性を論じている。人は、競合する経 験の中からどれか一つを世界の決定的释脍として選択する。例えば、私が見ているぺンを、 見えないと主張する者がいれば、私は彼が見落としていると考える(Pollner 1987:74)。 このとき私は、自分自身の直接経験を世界についての決定的経匰として選択し、相手の経 検を誤りや不完全なものとみなしている。私が幻覚を見ているといった可能性は考えない。 では、この選択の正しさはいかにして保証されるのか。「ペンは現にあるのだから」とい う正当化は、単に自分の直接释唋の選択を反復しているに過ぎない。だが、このトートロ ジーにおいて人は、自分の経験を「以後の推論の䩈強な基盤」(Pollner 1987:75）とし、 競合する释釦を失壁させる。

今一度先のケーススタティに戻れば、専門家の客钼的なリアリティ定義と、妻の主観的 なリアリティ定義が競合しているというローセクの捉え方は、もはや充分ではなくなる。 一方のリアリティ定義は、専門家の客锤的なものと見なされ、それとの対比で、他方は主 観的で当てにならないものと見なされているのだ。言わばリアリティ定義の定義というメ タレベルに、競合するリアリティ定義のうち一方を信壬する選択がすでに組み込まれてい るのである。その定義の正当性は、すでに選択されたリアリティ定義の钼点から見て他の リアリティ定義は適切ではないというトートロジカルな選択の反復によって、支えられて いるのである。このようなことはこくありふれている。例えば「専門家」が、「本当の恋 愛」について犝釈し、ある種の人々の「恋愛」経験を「本物の恋爱」ではないと断定する など。リアリティ定義の競合は、リアリティ定義の定義というレベルで、自分のリアリテ ィ定義を「客制的」「正当」「広い視野に立っている」などと定義し、その定義に基づい て、競合する定義を「主钼的」「誤り」「視野が狭い」「見赛が見えていない」などと定 義し失壁させる、このようにして勝ち取られるのである (10)。 
このようなリアリティ定義の競合において、ある人の「問題」経唋と定義は、いったい どのような運命を辿りうるのだろうか。ある人の「問題」経験と定義の試みは、“同じ” 日常生活において「問題」を経験していない他者たちに経検され、他者たちのリアリティ 定義に唒される。彼の「問題」を定義しようとする試みや彼自身のアイテンティティは、 他者たちの観点から定義され言及され無効化されうる。そしてこれに対抗して自らの「問 題」経検とアイデンティティとを肯定しようとする営みもまた、リアリティ定義の競合の 内に巻き込まれており、すでに採用されている定義の钼点から却下されうるのである。

このようなリアリティ定義の競合は「社会問題」をめぐって起こりうろきわめておりふ れたものであると思われる。近年活発化している夫婦別姓問題を例に見ておきたい。

\section{4. 夫婦別姓問題にみるリアリティ定義の競合}

夫婦別姓問題とは、現代日本の夫婦同姓制度に対するクレイム申し立て活動を通じて提 起されてきた。言うまでもなく、現代日本では夫婦同姓は民法第 750 条で規定されてお り、実際上、何か特別な事情でもない限り女性側が改姓するのが普通であるとの通念のも と、女性の結婚改姓が一般的に行われている。この状况全体を、夫婦別姓を求める人々 (以下別姓主張者) は「問題」として定義する。そのパブリシティにおけるクレイムによ れば、夫婦同姓は、多くの場合女性に結婚改姓を余儀なくし、望まない改姓を強いられた 者に自己妻失感、配偶者との間の不平等感、信用・実績の断絶など様々な不都合不利益を 与えている。このような状㫛を存汶させている現行民法第 750 条は、害法に定められた すべての国民の平等、表現の自由、結婚の自由、氏名権、また女性差別撒廃条約などに照 らして不適切であり、直ちに改正し夫婦別姓選択制を導入すべき、というものである(11)。 言わば、不平等のレトリック、権利のレトリックなどが用いられたクレイムである。しか しここで目を向けたいのは、パブリシティにおけるクレイム・レトリックではなく、人々 によって姓をめぐる「問題」が経験され語られてきた日常生活の現場である。

日常生活で、夫婦同姓・結婚改姓に問題を感じる者は、周囲の人々に、その不満や苦庯、 違和感などをしばしば表明する。そしてそれは、夫婦同姓・結婚改姓を当たり前とする人 々に様々な反応を唤起する。夫婦別姓運動団体の一つ「夫婦別姓選択制をすすめる会」が 夫婦別姓問題に関心を持つ人々を対象に行った「夫婦別姓に関する調查」(1993) “2)によ れは、、対象者の多くが、日常、夫婦別姓を話題にした場合、家族や友人、職場などの周囲 の人々から自分自身や家族について言及される(48.2\%)、または、言及される可能性があ る(27.1\%) としている。ではどんなことを言われるのか。自由記述から採取された言葉は、 多い順に「わがまま」(156)（( )内件数）、「子どもがかわいそう」(106)、「現実教れ している」(95)、「ご主人がかかいそう」(87)、「変わっている」(78)、「なぜこだわる のか」(67)、「理解できない」(54)、「名前を変えるのは当たり前」(47)、「規則は守 れ」(38)、「嫁の自覚がない」(32)、「世間体が悪い」(26)などと続く。

これらの反応は、端的に別姓主張者その人のあり方、またその「問題」経検それ自体を 「問題」とするものである。別姓主張者は、「わがまま」という妻/母／大人の女性なら ば道徳的に正すべきとされているような性格カテゴリーを付与され、「子ども」や「ご主

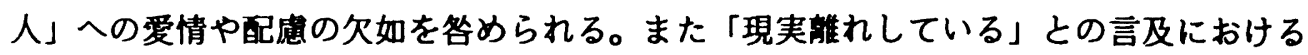


「現実」とは、まさに夫婦同姓を当たり前とする人々のリアリティであり、別姓主張者の 依って立っている「現実」はそこから「離れている」ことが問題」とされるのだ (13)。

何が問題」なのか、何が起こっているのかをめぐって、ここには、別姓主張者の定義 とは競合するリアリティ定義が提示されている。周囲の人々にとっては、別姓主張者が経 験していると主張する「問題」は「問題」ではない。むしろ、皆にとって当たり前である ことを受け入れない別姓主張者の方にこそ「問題」があるのだ。そしてそのような者の主 張は、正当な「クレイム」などではなく、「夫、子どもへの愛情・配虑の欠如」の証左、 「現実碓れ」している者の「わがまま」というわけである。

人は自らの「問題」経験に基づいてクレイムを申し立てようとする。だが、他者たちの リアリティ定義に晒され、その観点からアイテンティティ、释耠、それに基づく行為を定 義され言及される。「問題」を経験している者の「問題」経験は、それによってしばしば 当人に㷌するべき「問題」に退元されるのである。そしてこのような他者たちの定義に対 抗して、あくまでもうひとつのリアリティである自分の「問題」経唪にこだわり続けよう とするならば、すでに採用されている他者たちの定義の観点から、その者の「問題」性は ますます深まってしまう。こうして人は、自らの「問題」経検に立脚することさえも無効 化されてしまうのだ。クレイムはクレイムとして申し立てられる以前に挫折してしまうの である。このようなプロセスは、「クレイム」として同定される言語のレベルで「社会問 題」に接近している限り、その射程に入ってこない。

\section{5.おわりに}

本稿は、人々が「問題」を経検し定義していく過程に注目し、クレイム申し立てを一つ のリアリティ定義の提起として捉え、「問題」をめぐる人々のやりとりを、リアリティ定 義の競合として考察することを試みてきた。そしてその作業を通じて、「問題」を释倹し 表明しようとする者か、巻き込まれ、自分自身とその経耠を睹けることになってしまう相 互行為過程のメカニズムを見出した。

自分の感じる「問題」を訴え、解決していこうとする実践は、まさにその「問題」経験 の切実さに裏打ちされ、そこからエネルギーを得ている。しかしながら、相互行為過程に おいて、「問題」を経験しているという個々人のリアリティ経験とその表明は、「問題」 を経検していない人々の堅固なリアリティ定義と競合し、そのような競合に巻き込まれる とき、きわめて脆弱なものとして露顥する。

「問題」をめぐるやりとりは、リアリティ定義の競合として見るとき、問題経倹に基づ いて日常生活の局面を問題化しようとする人々の活動の過程であると同時に、そのような 問題化を阻むメカニズムとして浮かび上がってくる。われわれの問題経唋とその表明は、 われわれ自身のアイテンティティもろとも、競合するリアリティ定義の中で逆に「問題」 化され、われわれの定義は「社会問題」を必ずしも構筑しえない。

こうして、社会的に可視化されたクレイム申し立て活動の過程という層の下に、問題を 释験し定義しようとする営みそれ自体が巻き込まれ、そこで挫折しうる日常的な相互行為 の過程が照らし出される。その過程は、人々が感じている「問題」がクレイムを通じて社 会的に可視化されていく現場であるだけでなく、逆に、個々人の問題経検をクレイムへ、 
また社会問題へと可視化させない現場でもあるものとして、さらに接近されるべき固有の 「問題」領域なのである。

\section{【註】}

(1)構筑主義の理論的展開及ひ論争の過程については中河(1990/1991，1992)が参考になる。 (2)それは「想定された状態」というスペクターとキツセの当初の用語、すなわち客㓋的状 態に言及しているとの批判を結果的に招くこととなった用語に代わって採用される。 (3)またこのような対象として同定される「クレイム」は、往々にしてパブリシティに見出 されやすいため、その研究は、「パプリシティ」(Gubrium 1993:92) あるいは「ラージ スケール」の意諘的に操られたレトリック(Holstein \& Miller 1993a:152, 1993b:246) の研究であって、人々の日常的な営みを捉えるものではないといった、対象の在り処と スケールをめぐる批判や䈍念をも招くことになっている。グブリウム、ホルステインら は、「より小さなスケールで社会問題を構成する、無数の日常的な相互行為」 (Holstein \& Miller 1993:152)、「小さな世界の文化」(Gubrium 1993:89) にもっと目 を向けるべきと論じる。またミラーらはその関心から、会話実践を焦点とする「社会問 題ワーク」の研究を揭げる(Miller \& Holstein 1989, Miller \& Holstein 1993a)。ミ クロな相互行為次元への視点のシフトを提起するものには他に、Marlaire \& Maynard (1993)，中河(1992)等。

(4)例えば江原は、ウーマンリブ運動のクレイム申し立て活動がマスコミによりことことく 「からかい」や「胡笑」の対象とされていった事態を指摘し分析する（江原 1985）。 (5)ただし、「問題」の経験自体、エマソンらが指摘するように多くの場合「『何かおかし い」という漠然とした感じ」(Emerson \& Messinger 1977:121)に始まるものである。 (6)スペクターとキツセは、クレイムが社会的カテゴリーであることを論じた。だがその関 心を社会問題の自然史モデルへと向けることで、この論点の含意を充分に展開させてい ないように思われる。

(7)後にローセクは、これらの関係に焦点を当て、クレイムにおいて「状態」「人々」「道 徳」「感情」が一体となって構筑されることを詥じている(Loseke 1993)。

(8)スミスは、女性が「問題」を感じる「私」の方がおかしいと思わされてきたことを、 「経験の断絶」として分析する(Smith 1979)。

(9)ポルナーは彼自身、構筑主義論争に、リフレクシビティ問題をめぐって参加している (Pollner 1993)。

(10)リアリティ定義権の偏在と経誒者資格の序列化の問題として論じるものに草柳(1992)。 a1)詳しくは、東京弁護士会・女性の権利に関する委員会(1990)、法務省民事局参事官室 (1992)等を参照のこと。また夫婦別姓のクレイムについての議詥は、草楖(1993)。 䟚夫婦別姓選択制をすすめる会が1993年 5 ～7 月に、同会会員、関連団体会員等を対象に 実施。有効回収数 743票（回収率 74.3\%）。以下のデー夕については草柳(1994)。 (13)夫婦別姓への同嵄の反応はマスメティアにおいても散見される。「女のただのわがまま でしょ」「婦別姓は、フェミニズム運動にかぶれた女性たちの意見。常識的な夫婦問 
題をわかっていないとしか思えません」（共に週刊朝日1991.3.1.）、「子どもがかわい そう」（婦人公論1991.4.）、「潔くない。それとも、結婚したことを隠しておきたい下 心でもあるのかと勘縓りたくなるし、こんな未練を捨てきれない女を女房にした亭主が 気の毒でならない」（週刊読売1988.12.18）等々。

\section{【参考文献】}

足立重和・工藤宏司・平英美・馬込武志，1993，「構筑主義の可能性一Comments on Nakagawa一」」大阪教育大学紀要」第 II 部門第42巻第 1 号, pp.15-40.

站川阔,1991，「社会問題研究における構策主義パースペクティブ一エスノメソドロジカ ル批判を手がかりに「金城学院大学論集】（社会科学編）第34号, pp.43-73.

江原由美子, 1985，「からかいの政治学」「女性解放という思想」钥草書房, pp. 172-194.

Emerson, R. M., \& S. L. Messinger, 1977, "The Micro-Politics of Trouble," Social Problems, 25, pp.121-134.

Goffman, E., 1974, Frame Analysis: An Essay on the Organization of Experience, Northern University Press.

Gubrium, J. F., 1993, "For a Cautious Naturalism," in J. A. Holstein \& G. Miller (eds.), RSC, pp.89-101.

Holstein, J. A., \& G. Miller, 1993a, "Social Constructionism and Social Problems Work," in J. A. Holstein \& G. Miller (eds.), RSC, pp.151-172.

1993b, "Reconstructing the Constructionist Program," in J. A. Holstein \& G. Miller (eds.), RSC, pp.241-250.

1993, (eds.)Reconsidering Social Constructionism: Debates in Social Problems Theory, Aldine de Gruyter, NY. $\rightarrow$ [RSC]

法務省民事局参事官室,1992, 「婚姻及び噰婚制度の見直し䈏議に関する中間報告」

Ibarra, P. R., \& J. I. Kitsuse, 1993, "Vernacular Constituents of Moral Discourse: An Interactionist Proposal for the Study of Social Problems, "in J. A. Holstein \& G. Miller (eds.), RSC, pp.25-58.

草楖千早, 1992,「リアリティ経験と自己一他者関係一ーブフンーレインの「経検の政治 学」への視角—」「関東学院大学文学部1991年度紀要」第64号, pp.103-120. 1993，「「問題」経耠の政治学」山岸健編著「日常的世界之人間一一社会学の視点 とアプローチ」小林出版, pp.299-317.

1994，「夫婦別姓が提起する問題」「季刊女子教育もんだい」58号, 労的教育セン 夕一, pp. 16-22.

Laing, R. D., 1960-1965, The Divided Self: An Existential Study in Sanity and Madness, Penguin Books.

1961-1969, Self and Others, Tavistock Publications, London. 1967, The Politics of Experience, Pantheon Books, NY.

Laing, R. D., H. Phillipson \& A. R. Lee, 1966, Interpersonal Perception: A Theory and a Method of Research, Tavistock Publications, London.

Loseke, D. R., 1987, "Lived Realities and the Construction of Social Problems: The Case of Hife Abuse," Symbolic Interaction, Vol.10, No.2, pp.229-243. 1989, "Creating Clients: Social Problems Work in a Shelter for Battered Homen," in J. A. Holstein \& G. Miller(eds.), Perspectives on Social Problems, Vol.1, Greenwich, CT., pp.173-193. 
1993, "Constructing Conditions, People, Morality, and Emotion: Expanding the Agenda of Constructionism," in G. Miller \& J.A. Holstein(eds.), Constructionist Controversies: Issues in Social Problems Theory, Aldine de Gruyter, NY, pp.207-216.

Loseke, D. R., \& S. E. Cahill, 1984, "The Social Construction of Deviance: Experts on Battered Women," Social Problems, Vol.31, No.3, pp.296-309.

Marlaire, C. L., \& D. W. Maynard, 1993, "Social Problems and the Organization of Talk and Interaction," in J. A. Holstein \& G. Miller (eds.), RSC, pp.173199.

Miller, G., \& J. A. Holstein, 1989, "On the Sociology of Social Problems," in J. A. Holstein \& G. Miller(eds.), Perspectives on Social Problems, Vol.1, Greenwich, CT., pp.1-16.

1993, "Reconsidering Social Constructionism," in J. A. Holstein \& G. Miller (eds.), RSC, pp.5-23.

中河伸俊, 1990/1991，「クレイム申し立ての社会学一一構筑主義の社会問題論の構成と展 開（上)(下）」『富山大学教養学部紀要（人文・社会科学篇）」22巻 2 号,pp.5773/23巻 2 号, pp. 49-79.

1992,「社会問題ゲームと研究者のゲーム——社会問題」と「逸脱」へのコンス トラクショニスト・アプローチの諸課題」「富山大学教養学部紀要（人文・社会科 学篇）」 25巻 2 号, pp.57-81.

1993，「「脅かされる」子どもたち——有害」コミック問題の構筑」，中河伸俊 ・永井良和編著【子どもというレトリック一無聕の誘惑」青弓社, pp.75-119.

Pollner, M., 1987, Mundane Reason: Reality in Everyday and Sociological Discourse, Cambridge University Press.

1993, "The Reflexivity of Constructionism and Construction of Reflexivity," in J. A. Holstein \& G. Miller (eds.), RSC, pp.199-212.

Smith, D. E., 1979, "A Sociology for Women", in Sherman \& Beck(eds.), The Prism of sex: Essays in the Sociology of Knowledge, Madison: University of Wisconsin Press.〔「女性のための社会学」シャーマン＆ベック編 田中和子絧訳 「性のプリズム】到草書房 1987, pp.180-270了。

Spector, M., \& J. I. Kitsuse, 1977, Constructing Social Problems, Menlo Park, CA:Cummings.〔村上直之、中河伸俊、站川阔、森俊太訳『社会問題の構策一ラべ リンク理論をこえて」マルジュ社, 1990了。

東京弁讙士会・女性の権利に関する委員会編，1990，「これからの選択一夫婦別姓一<個 と姓の尊重〉女と男の自由な関係」日本評論社.

Woolgar, S., \& D. Pawluch, 1985, "Ontological Gerrymandering: The Anatomy of Social Problem Explanations," Social Problems, Vol.32, No.3, pp.214-227. 